\title{
Update on the distribution of the Andean cat Oreailurus jacobita and the pampas cat Lynchailurus colocolo in Peru
}

\author{
E. Daniel Cossíos ${ }^{1, *}$, Analí Madrid ${ }^{2}$, José Luis Condori ${ }^{3}$, Ursula Fajardo ${ }^{4}$ \\ ${ }^{1}$ Département de Sciences Biologiques, Université de Montréal, CP 6128, Succ. Centre-Ville, Montréal H3C 3J7, Canada \\ ${ }^{2}$ Perú Ecológico, Urb. Los Girasoles de Huampaní Mzna, OHB Lote 2, Lima 08, Peru \\ ${ }^{3}$ Calle J. Santos Atahualpa E-3 Cerro Colorado, Arequipa, Peru \\ ${ }^{4}$ Museo de Historia Natural de la Universidad de San Marcos, Av. Arenales 1256, Jesús María, Lima 14, Peru
}

\begin{abstract}
We review the current distribution of the Andean cat Oreailurus jacobita and the pampas cat Lynchailurus colocolo in Peru and present 30 new records of the Andean cat and 268 of the pampas cat between the years 2001 and 2006. In addition, we evaluate the presence of the Andean cat from interviews with local inhabitants. These new records extend the known Andean cat distribution an extra $892 \mathrm{~km}$ northwest and show that pampas cats occupy a great diversity of habitats throughout the Peruvian coast and Andes.
\end{abstract}

KEY WORDS: Andean cat $\cdot$ Distribution $\cdot$ Pampas cat $\cdot$ Peru

Resale or republication not permitted without written consent of the publisher

\section{INTRODUCTION}

The Andean cat Oreailurus jacobita Cornalia, 1865 and the pampas cat Lynchailurus colocolo Molina, 1782 are 2 small cat species from South America. There is a lack of knowledge about the ecology and biology of both species and their distribution in Peru remains obscure.

The Andean cat is one of the rarest felid species in the world (Nowell \& Jackson 1996, Chapron 1999). It is found only in the highlands of Peru, Bolivia, Chile and Argentina (Villalba et al. 2004). Only 2 records of this species have been reported in Peru: Pearson (1957) reported an Andean cat in the Arequipa department, and Grimwood (1969) observed this species near Azangaro, in the department of Puno (Fig. 1). Due to the extremely scarce observations in the field, its low population sizes, and the many threats that it faces, the Andean cat is listed as 'Endangered' by the IUCN the World Conservation Union (IUCN 2006) as well as by the Peruvian government (Decreto Supremo No. 034-2004-AG).
The pampas cat is more common than the Andean cat with a distribution encompassing central Ecuador to Patagonia (Nowell \& Jackson 1996). It can be found in a great variety of habitats, including grasslands, the Brazilian Cerrado and many types of forests (Nowell \& Jackson 1996). Its large morphological variability led García-Perea (1994) to propose that it be split into 3 different species, whereas analyses of mitochondrial DNA diversity suggest it should be considered a single species (Johnson et al. 1999). Although the pampas cat is relatively common, its distribution in Peru is not well known. Furthermore, publications of its global distribution usually fail to include local reports and grey literature.

Both felid species are hunted for their skins, to obtain stuffed cats or body parts for use in magic/religious ceremonies and folk dances, to decrease potential predation on domestic animals, for superstitious reasons or for sport (Villalba et al. 2004). In addition, the pampas cat could be an important competitor of the Andean cat because of the similarity of their diets (Lucherini \& Luengos 2003, Perovic et al. 2003, Villalba et al. 2004). 


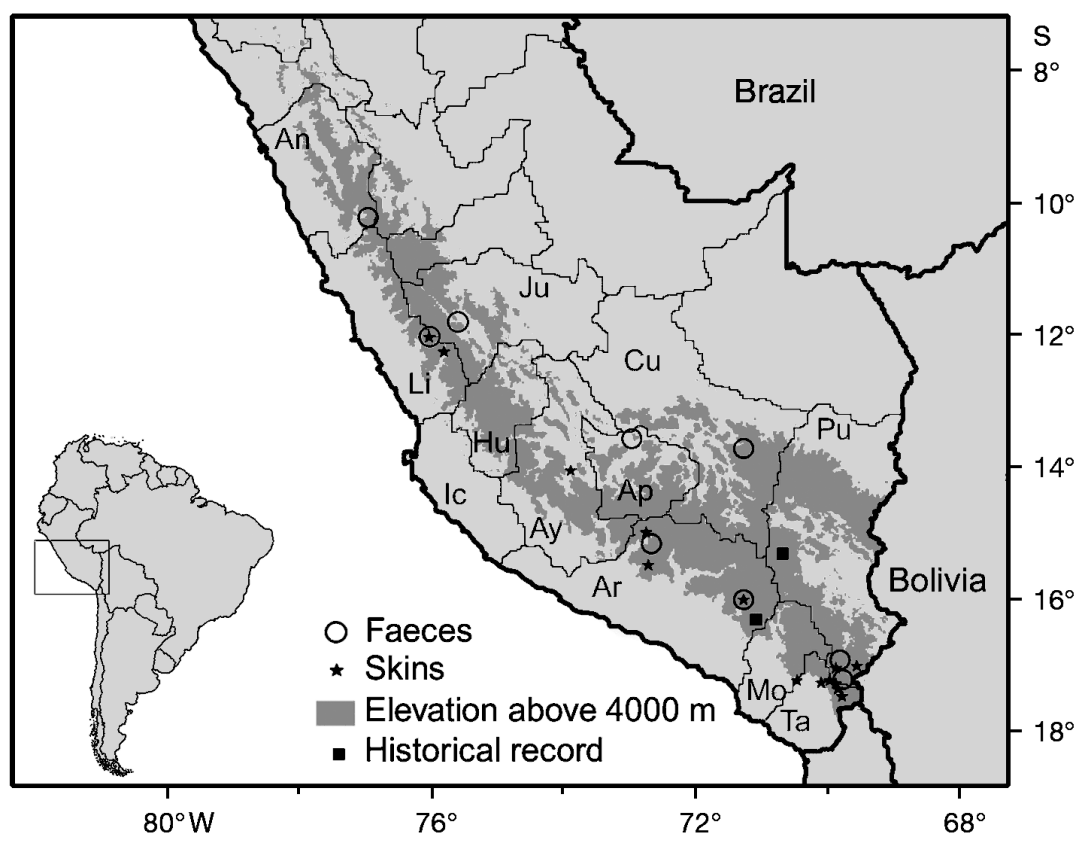

Fig. 1. Oreailurus jacobita. Andean cat distribution in Peru. Historical records in Puno and Arequipa departments are from Grimwood (1969) and Pearson (1957), respectively. An: Ancash; Li: Lima; Ju: Junin; Ic: Ica; Hu: Huancavelica; Ay: Ayacucho; Cu: Cuzco; Ap: Apurimac; Ar: Arequipa; Pu: Puno; Mo: Moquegua; Ta: Tacna

For the effective planning of conservation strategies for these cat species, better knowledge about their status across Peru is needed. In the present paper, the distributions of the Andean and pampas cats in Peru are updated based on new records.

\section{MATERIALS AND METHODS}

We describe the distributions of Andean and pampas cats based on observations we made in the field and on records published by other authors. Our observations were made between 2001 and 2006, principally above an altitude of $3000 \mathrm{~m}$ in central and southern Peru, but they also include anecdotal observations from the northern regions as well as below this altitudinal limit.

Survey areas were chosen according to their altitude (3000 $\mathrm{m}$ or more) and previous information about the possible presence of Andean cats (historical records and data given by rangers in protected areas, mountain guides or field biologists).

Our observations include sightings of live or dead animals, skins and stuffed specimens owned by rural inhabitants, skulls, and faeces collected by various researchers and identified in the laboratory.

Sightings, skins and skulls were identified with the criteria presented by García-Perea (2002) and Cossíos et al. (2007). People who owned skins or stuffed cats were interviewed to determine the approximate site where the animals were hunted. Faecal samples were collected in paper bags and preserved with silica gel (Cossíos et al. 2007) and identified by DNA analysis with the protocol presented by Cossíos \& Angers (2006) or by mitochondrial DNA control region sequencing. Some skins and dead animals were sent to the San Marcos Natural History Museum (Lima, Peru) or to the San Agustin National University Museum (Arequipa, Peru). A total of 378 man-days were used for field survey, including 212 man-days spent on the search for faecal samples.

Because of the rarity of the Andean cat, in addition to the search for direct evidence of its presence, interviews with local inhabitants were conducted to assess its distribution. Local inhabitants were asked to give the location and date of sightings and to describe the observed felid species, special attention being given to the description of the tail, which is characteristic in the Andean cat (Chapron 1999). When the interviewer did not have confidence in the answers given, interviews were discarded. The ratio $n / \mathrm{N}_{\text {, }}$ where $\mathrm{N}$ is the number of interviews done in a region and $\mathrm{n}$ is the number of positive answers about Andean cat presence, was used as an indicator of the relative abundance of the Andean cat in each of the regions visited (Chapron 1999). Although interviews have limitations (e.g. credibility of the interviewees and probable differences in detection probability throughout the evaluated area), this method is considered to be effective in assessing the presence of elusive or rare species (González \& González 1996, Schaller et al. 1996, Chapron 1999).

\section{RESULTS}

We obtained 30 new records for the Andean cat, and 268 for the pampas cat in Peru. In addition, we evaluated the presence of the Andean cat from interviews with local residents.

For the Andean cat, 19 of the records were skins owned by villagers and 11 were faecal samples (Table 1). With these results, the currently known distribution for the Andean cat in Peru now includes the Puna and Altoandino geographic provinces, in the 
Table 1. Oreailurus jacobita. Andean cat records between 2002 and 2006

\begin{tabular}{|c|c|c|c|c|c|}
\hline Department/province/locality & South & West & Skins & Faeces & Year \\
\hline Tacna/Tarata/Kallapuma & $17^{\circ} 19^{\prime} 02.66^{\prime \prime}$ & $69^{\circ} 43^{\prime} 51.77^{\prime \prime}$ & 1 & & 2005 \\
\hline Tacna/Tarata/Tacjata & $17^{\circ} 10^{\prime} 24.61^{\prime \prime}$ & $69^{\circ} 58^{\prime} 12.82^{\prime \prime}$ & 2 & & 2005 \\
\hline Tacna/Candarave/Tacalaya & $17^{\circ} 06^{\prime} 07.7^{\prime \prime}$ & $70^{\circ} 23^{\prime} 48.73^{\prime \prime}$ & 3 & & 2004 \\
\hline Puno/El Collao/near Kovire & $17^{\circ} 10^{\prime} 57.86^{\prime \prime}$ & $69^{\circ} 54^{\prime} 51.31^{\prime \prime}$ & 1 & & 2002 \\
\hline Puno/El Collao/near Jijuaña & $17^{\circ} 13^{\prime} 50.57^{\prime \prime}$ & $69^{\circ} 53^{\prime} 40.2^{\prime \prime}$ & 3 & & 2002 \\
\hline Puno/El Collao & $16^{\circ} 42^{\prime} 37.23^{\prime \prime}$ & $69^{\circ} 43^{\prime} 37.23^{\prime \prime}$ & & 1 & 2005 \\
\hline Puno/El Collao & $17^{\circ} 08^{\prime} 09.81^{\prime \prime}$ & $69^{\circ} 41^{\prime} 54.85^{\prime \prime}$ & & 1 & 2005 \\
\hline Puno/Lampa & $15^{\circ} 15^{\prime} 28.56^{\prime \prime}$ & $70^{\circ} 27^{\prime} 38.34^{\prime \prime}$ & 1 & & 2004 \\
\hline Puno/Chucuito/Chichillapi & $16^{\circ} 55^{\prime} 47.58^{\prime \prime}$ & $69^{\circ} 48^{\prime} 19.55^{\prime \prime}$ & 1 & & 2005 \\
\hline Puno/Chucuito/near Pisacoma & $16^{\circ} 55^{\prime} 00.36^{\prime \prime}$ & $69^{\circ} 29^{\prime} 03.85^{\prime \prime}$ & 1 & & 2002 \\
\hline Arequipa/Arequipa/Pillones & $15^{\circ} 56^{\prime} 07.41^{\prime \prime}$ & $71^{\circ} 14^{\prime} 45.43^{\prime \prime}$ & 1 & 1 & 2004 \\
\hline Arequipa/Koyajo & $15^{\circ} 26^{\prime} 00.87^{\prime \prime}$ & $72^{\circ} 41^{\prime} 10.47^{\prime \prime}$ & 1 & & 2002 \\
\hline Arequipa/Huactapa & $14^{\circ} 59^{\prime} 22.25^{\prime \prime}$ & $72^{\circ} 42^{\prime} 53.97^{\prime \prime}$ & 1 & & 2002 \\
\hline Arequipa/Unión & $15^{\circ} 07^{\prime} 22.40^{\prime \prime}$ & $72^{\circ} 39^{\prime} 58.96^{\prime \prime}$ & & 2 & 2004 \\
\hline Ayacucho/Sucre/Tintay & $14^{\circ} 04^{\prime} 43.57^{\prime \prime}$ & $73^{\circ} 51^{\prime} 54.98^{\prime \prime}$ & 1 & & 2002 \\
\hline Cuzco/Canchis/Auzangate & $13^{\circ} 44^{\prime} 37.04^{\prime \prime}$ & $71^{\circ} 12^{\prime} 14.83^{\prime \prime}$ & & 1 & 2004 \\
\hline Apurimac/Abancay/Pachacpata & $13^{\circ} 35^{\prime} 47.60^{\prime \prime}$ & $72^{\circ} 58^{\prime} 08.75^{\prime \prime}$ & & 1 & 2004 \\
\hline Lima/Yauyos/Laraos & $12^{\circ} 20^{\prime} 00^{\prime \prime}$ & $75^{\circ} 47^{\prime} 00^{\prime \prime}$ & 1 & & 2006 \\
\hline Lima/Yauyos/Tanta & $12^{\circ} 07^{\prime} 00^{\prime \prime}$ & $76^{\circ} 01^{\prime} 00^{\prime \prime}$ & 1 & & 2006 \\
\hline Lima/Yauyos/Tanta & $12^{\circ} 04^{\prime} 08.01^{\prime \prime}$ & $75^{\circ} 56^{\prime} 52.06^{\prime \prime}$ & & 1 & 2006 \\
\hline Junin/Jauja/Canchayllo & $11^{\circ} 49^{\prime} 27.53^{\prime \prime}$ & $75^{\circ} 41^{\prime} 59.07^{\prime \prime}$ & & 1 & 2006 \\
\hline Ancash/Bolognesi/Huayhuash & $10^{\circ} 13^{\prime} 26.03^{\prime \prime}$ & $76^{\circ} 57^{\prime} 16.28^{\prime \prime}$ & & 2 & 2006 \\
\hline Total & & & 19 & 11 & 30 \\
\hline
\end{tabular}

highlands from the southern (Puno, Tacna, Cuzco, Apurímac, Ayacucho and Arequipa departments) and central regions of the country (Lima, Junin and Ancash departments) (Fig. 1). The lowest altitude at which this species was recorded was $3326 \mathrm{~m}$ at Pachacpata, Apurímac, and the highest at $4804 \mathrm{~m}$ at Auzangate, Cuzco. The percentage of people interviewed who confirmed having seen Andean cats (when different from $0 \%$ ) ranged from $6.1 \%$ (Central Ancash) to

Table 2. Oreailurus jacobita. Results of interviews relating to the presence of Andean cats by region. $\mathrm{N}=$ total number of interviews; $\mathrm{n}=$ number of people interviewed who said they had seen Andean cats

\begin{tabular}{|lccc|}
\hline Region & $\mathrm{N}$ & $\mathrm{n}$ & $\mathrm{n} / \mathrm{N} \times 100$ \\
\hline Tacna & 109 & 71 & 65.14 \\
Southern Puno & 56 & 48 & 85.71 \\
Northern Puno & 56 & 36 & 64.29 \\
Arequipa & 163 & 88 & 53.99 \\
Huancavelica & 38 & 16 & 42.11 \\
Cuzco & 13 & 3 & 23.08 \\
Apurimac & 38 & 16 & 42.11 \\
Northern Ayacucho & 75 & 21 & 28.00 \\
Southern Ayacucho & 47 & 4 & 8.51 \\
Northern Junin & 12 & 2 & 16.67 \\
Southern Lima & 21 & 14 & 66.67 \\
Central Lima & 15 & 4 & 26.67 \\
Southern Ancash & 20 & 14 & 70.00 \\
Central Ancash & 33 & 2 & 6.06 \\
Total & $\mathbf{6 9 6}$ & $\mathbf{3 3 9}$ & \\
\hline
\end{tabular}

85.7\% (Southern Puno) (Table 2). All the faeces sampling sites and the descriptions of sites where villagers reported having seen Andean cats corresponded to rocky environments with a vegetation dominated by herbs and the presence of viscachas Lagidium sp., Rodentia, which is one of the principal prey species of the Andean cat (Villalba et al. 2004, Walker et al. 2007).

The sites where we recorded skins or faeces of this species included the following 4 protected areas: Zona Reservada Aymara Lupaca (Puno), Reserva Nacional Salinas y Aguada Blanca (Arequipa), Reserva Paisajistica Subcuenca del Cotahuasi (Arequipa) and Reserva Paisajística Nor Yauyos Cochas (Lima).

For the pampas cat, we obtained direct signs of presence (sightings, faeces, skins) and positive interviews throughout the entire area evaluated, with the exception of areas near big cities and some other specific sites. Some of the faecal samples were collected very close to villages, $100 \mathrm{~m}$ or less. Among the direct records for this species, 5 were sightings of live animals, 5 were dead animals, 67 were skins or stuffed cats owned by villagers and 191 were faecal samples (Appendix 1). The known distribution for the pampas cat in Peru (Fig. 2) covers the Andes and includes the puna grasslands, high Andean forests, valleys, dry forests and some coastal hills, between $400 \mathrm{~m}$ (Atiquipa in Arequipa, Zeballos et al. 2000; and Lachay in Lima, Ramírez et al. 2001) and $4982 \mathrm{~m}$ above sea level (Ancash department, central Peru). 


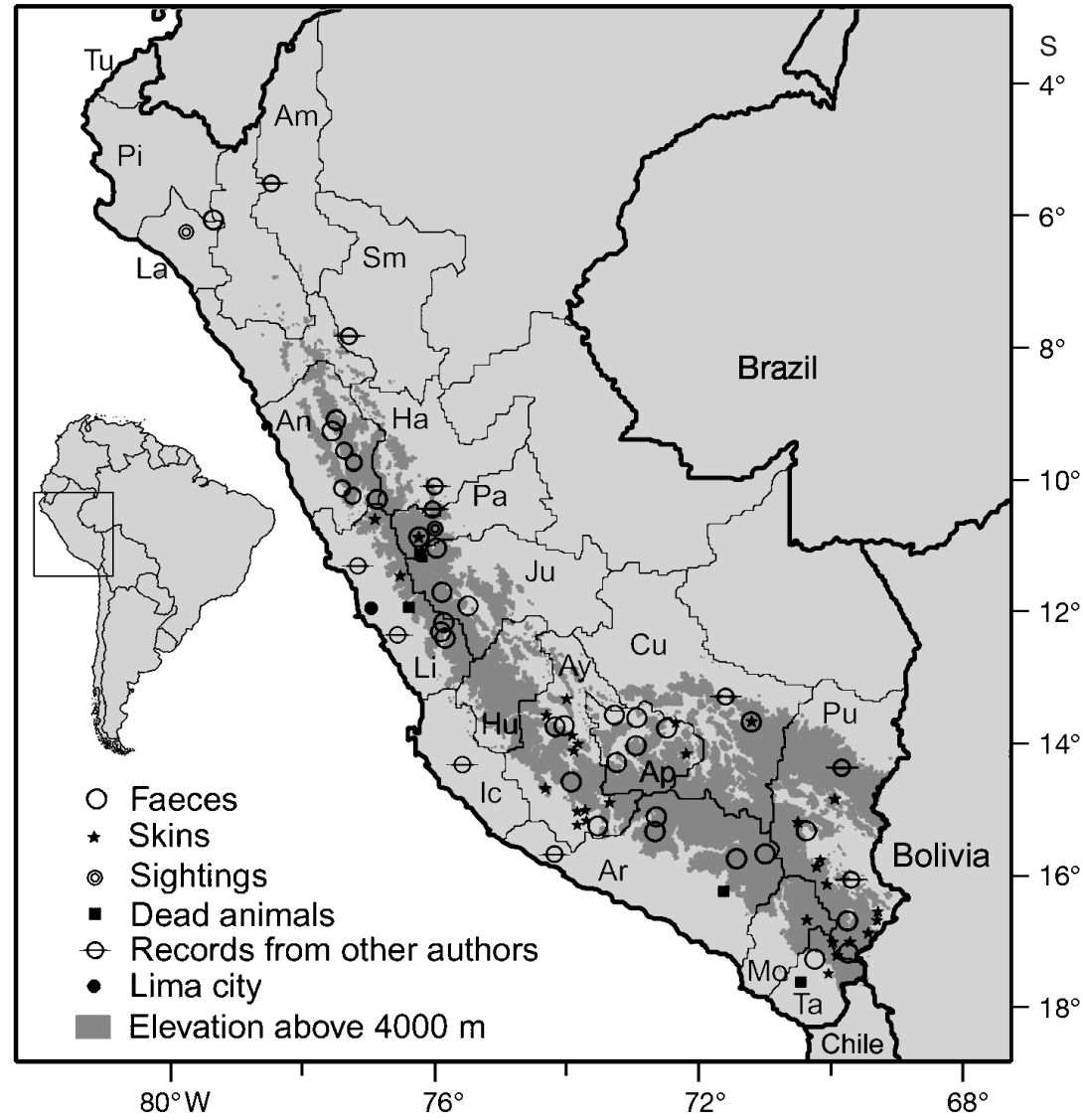

Fig. 2. Lynchailurus colocolo. Pampas cat distribution in Peru. Tu: Tumbes; Pi: Piura; Am: Amazonas; La: Lambayeque; Sm: San Martin; An: Ancash; Ha: Huanuco; Pa: Pasco; Li: Lima; Ju: Junin; Ic: Ica; Hu: Huancavelica; Ay: Ayacucho; $\mathrm{Cu}$ : Cuzco; Ap: Apurimac; Ar: Arequipa; Pu: Puno; Mo: Moquegua; Ta: Tacna

\section{DISCUSSION AND CONCLUSIONS}

The Andean cat distribution in Peru is larger than suspected based on the information available prior to this study. The new records presented here extend its range an extra $892 \mathrm{~km}$ northwest and show that this felid is present in 9 departments and 4 protected areas. Faecal samples from the extreme south of the Ancash department suggest that the Andean cat could be present in 2 additional nearby protected areas: Reserva Paisajistica Huayhuash and Parque Nacional Huascaran.

Although the sampling effort varied between localities, the quantity of signs of presence (Table 1) and the percentage of positive interviews for the Andean cat (Table 2, Fig. 3) show that this species is more common in the extreme south of the country (south of Puno and Tacna, with $85.71 \%$ positive interviews), followed by southern Ancash $(70 \%)$, southern Lima $(66.67 \%)$, northern Puno (64.29\%) and the Arequipa department $(53.99 \%)$. These results show that there are variations in the probability of detection at different sites, this probably being due to variations in abundance or to a fragmented distribution.

The Andean cat seems to be especially rare in Ayacuho and Cuzco, and it is probably absent in northern Junin (in the surroundings of the Junin National Reserve) and in central Ancash, regions that are both on the northern boundary of the known distribution of this species. The presence of the Andean cat in the extreme south of Peru is consistent with the records and observations presented by Chapron (1999), Sanderson (1999), Villalba et al. (2004) and A. Iriarte (unpubl.) for northern Chile and northwestern Bolivia, which would indicate that the neighbouring zone between these 3 countries is an important area for the conservation of this felid species. To improve our knowledge of the Andean cat distribution, we recommend that surveys assessing the presence/absence of cats be conducted in Moquegua, southern Cuzco and the northern Lima departments, from which few or no data are currently available, as well as in northern Puno and Huancavelica, where only interviews were conducted. Information taken from the interviews samples, $\mathrm{n}=35$ ). 


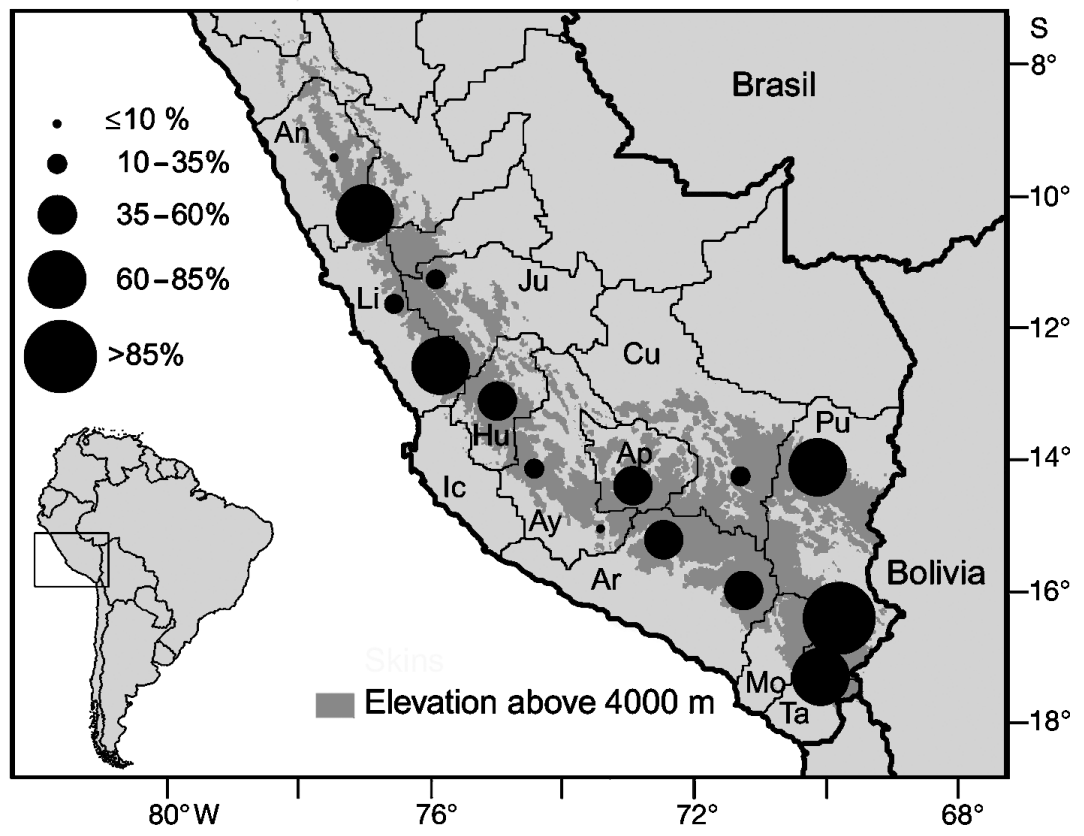

Fig. 3. Oreailurus jacobita. Relative abundance of Andean cats in Peru, estimated from interviews with local inhabitants. Size of black circles reflects the percentage of people interviewed who said they had seen Andean cats. An: Ancash; Li: Lima; Ju: Junin; Ic: Ica; Hu: Huancavelica; Ay: Ayacucho; Cu: Cuzco; Ap: Apurimac; Ar: Arequipa; Pu: Puno; Mo: Moquegua; Ta: Tacna
Andean region, from Piura in the north to Puno in the south' and he mentioned that this species was also present in the northern Amazonas and Tumbes departments. However, the current distribution of this species in the northern part of Peru is not well known and further research is needed. Grimwood (1969) mentioned the presence of the pampas cat in 'the upper part of the Manu National Park', even though the list of mammalian fauna presented by Solari et al. (2006) for this protected area does not include this species. This discrepancy could be due to a rare or occasional presence of the pampas cat in the area, to the limited accuracy of the methods used by Grimwood (1969), or to a recent local extinction.

In addition to the threats to cats reported by Villalba et al. (2004), we determined that wild cats in Peru are also killed for use in popular medicine, for consumption, and to reduce predation on aquatic fowl. The reasons for hunting cats differ in would be used to determine the best locations to pursue surveys and further research. Then, faecal sampling or another method would be used to confirm the presence of the species.

Contrary to what García-Perea (1994) showed, the pampas cat is common on the western slope of the Peruvian Andes. García-Perea (1994) considers that the pampas cats from northern Chile belong to the subspecies Lynchailurus colocolo wolfshoni and that they are different than the varieties described for the Peruvian Andes (L. C. garleppi) and the Bolivian Andes (L. C. steinbachi). Other authors, however, recognize a single subspecies for the region that includes southern Peru, northern Chile and northwestern Bolivia (e.g. Johnson et al. 1999). Due to the lack of evident geographic barriers between the Peruvian and Chilean Andes, we believe that the pampas cats from the western Andean slope of both countries belong to the same subspecies.

We did not extensively monitor the northern region of the country, even though there are a few pampas cat records from San Martin (Romo 1995, San Marcos University Natural History Museum unpubl.), Amazonas (García-Perea 1994) and Lambayeque (present research). Grimwood (1969) made local enquiries in a large part of the country and concluded that the pampas cat was 'present in almost every department of the different regions. The use of wild cats in magic/ religious ceremonies and dances, and pursuit for superstitious reasons, are more common in the southern region of the country (Puno, Tacna and Arequipa departments), while their consumption, use in popular medicine and killings to reduce predation of fowl were recorded only in specific sites in central Peru. On the other hand, inter-specific competition between Andean and pampas cats could be a factor that affects the Andean cat populations in central Peru more than those in the south. These differences must be considered for the development of local conservation programs.

Because of the apparent rarity of the species, even occasional Andean cat hunting could cause its local extinction (Perovic et al. 2003). In southern Peru, where hunting seems to be more common, the risk of extinction due to this factor could be even greater. The threats posed by human attitudes towards the felid species, in addition to the loss and fragmentation of their habitat, may be reducing populations of the Andean and pampas cats in many areas throughout their range.

Acknowledgements. This work was supported by grants from the Wildlife Conservation Network, Cat Action Treasury and the Panthera/Wildlife Conservation Society Kaplan Awards 
Program. We thank the Instituto Nacional de Recursos Naturales (INRENA) for its logistic support, Marco Arenas Aspilcueta, the director of Reserva Nacional Salinas y Aguada Blanca and all the personnel of the protected areas we visited. A special acknowledgement to Víctor Pacheco, from the Museo de Historia Natural de la Universidad Nacional de San Marcos (MUSM), to Bernard Angers and Emilie Castonguay for their help and comments, and to the people who assisted us: Melecio Arias, Daniel Ascencios, Pilar Ayala, Auri Cangalaya, Susy Castillo, Iris Deustua, Víctor Gamarra, Elizabeth Gonzales, Antenor Huamán, Deyvis Huamán, Alexander Jiménez, Roberto Ledesma, Juan Nugent, Yammil Ramírez, Sergio Ramirez-Carrascal, William Ramos, Carlos Sánchez, Walter Santacruz and Gonzalo Quiroz, and to all the people who patiently answered our questions, showed us stuffed animals and gave us a hand in the field.

\section{LITERATURE CITED}

Chapron G (1999) Évaluation du statut du chat des Andes (Oreailurus jacobita) par interviews des populations locales dans les Andes centrales. Recl Med Vet 175:119-125

Cossíos ED, Angers B (2006) Identification of Andean felid feces using PCR-RFLP. J Neotrop Mammal 13:239-244

Cossíos ED, Beltrán Saavedra F, Bennet M, Bernal N and others (2007) Manual de metodologías para relevamientos de carnívoros altoandinos. Alianza Gato Andino, Buenos Aires

García-Perea R (1994) The pampas cat group (Genus Lynchailurus Severtzov, 1858) (Carnivora: Felidae), a systematic and biogeographic review. Am Mus Novit 3096:1-35

García-Perea R (2002) Andean mountain cat, Oreailurus jacobita: morphological description and comparison with other felines from the Altiplano. J Mammal 83:110-124

González JO, González JG (1996) Situación del lince ibérico en Sierra de Gata. Doñana. Acta Vertebr 23:91-98

Grimwood IR (1969) Notes on the distribution and status of some Peruvian mammals 1968. Special Publication No. 21. New York Zoological Society, New York

IUCN (The World Conservation Union) (2006) 2006 IUCN red list of threatened species. Available at: www.iucn redlist.org. Accessed on 26 April 2007
Johnson WE, Pecon Slattery J, Eizirik E, Kim J and others (1999) Disparate phylogeographic patterns of molecular genetic variation in four closely related South American small cat species. Mol Ecol 8:S79-S94

Lucherini M, Luengos E (2003) Intraguild competition as a potential factor affecting the conservation of two endangered cats in Argentina. Endang Spec Update 20: $211-220$

Nowell K, Jackson P (eds) (1996) Wild cats, status survey and conservation action plan. IUCN/SSC Cat Specialist Group. IUCN, Gland

Pearson OP (1957) Additions to the mammalian fauna of Peru and notes on some other Peruvian mammals. Breviora 73:1-7

Perovic P, Walker S, Novaro A (2003) New records of the endangered Andean mountain cat at high altitudes in Northern Argentina. Oryx 37:374-377

Ramírez O, Arana M, Kunimoto C, De la Cruz C, Guabloche A (2001) Lista comentada de los mamíferos no voladores de la Reserva Nacional de Lachay. Biota 100:108-113

Romo MC (1995) Food habits of the Andean fox (Pseudalopex culpaeus) and notes on the mountain cat (Felis colocolo) and puma (Felis concolor) in the Río Abiseo National Park, Perú. Mammalia 59:335-343

Sanderson J (1999) Andean mountain cats (Oreailurus jacobita) in Northern Chile. Cat News 30:25-26

Schaller GB, Liu W, Wang X (1996) Status of Tibet red deer. Oryx 30:269-274

Solari S, Pacheco V, Luna L, Velazco PM, Patterson BD (2006) Mammals of the Manu Biosphere Reserve. In: Patterson BD, Stotz DF, Solari S (eds) Mammals and birds of the Manu Biosphere Reserve, Peru-Fieldiana, Zoology, New Ser 110. Field Museum of Natural History, Chicago, IL, p 13-23

Villalba L, Lucherini M, Walker S, Cossíos D and others (2004) The Andean cat: a conservation action plan. Andean Cat Alliance, La Paz

Walker S, Novarro A, Perovic P, Palacios R and others (2007) Diet of three species of Andean carnivores in high-altitude deserts of Argentina. J Mammal 88:519-525

Zeballos H, Villegas L, Gutiérrez R, Caballero K, Jiménez P (2000) Vertebrados de las lomas de Atiquipa y Mejía, sur del Perú. Rev Ecol Latinoam 7:11-18

Appendix 1. Lynchailurus colocolo. Pampas cat records in Peru from this research

\begin{tabular}{|c|c|c|c|c|c|c|c|c|}
\hline Department/locality & South & West & Altitude (m) & Skins & Dead cats & Scats & Sights & Year \\
\hline Tacna/Kovire & $17^{\circ} 13^{\prime} 08^{\prime \prime}$ & $69^{\circ} 54^{\prime} 51^{\prime \prime}$ & 4318 & 1 & & & & 2002 \\
\hline Tacna/Tarata & $17^{\circ} 29^{\prime} 40^{\prime \prime}$ & $70^{\circ} 02^{\prime} 08^{\prime \prime}$ & & 6 & & & & 2005 \\
\hline Tacna/Candarave & $17^{\circ} 17^{\prime} 24^{\prime \prime}$ & $70^{\circ} 14^{\prime} 35^{\prime \prime}$ & & & & 1 & 2 & $2004 / 2005$ \\
\hline Tacna & $17^{\circ} 25^{\prime} 12^{\prime \prime}$ & $69^{\circ} 57^{\prime} 49^{\prime \prime}$ & & 1 & & & & 2004 \\
\hline Tacna & $17^{\circ} 38^{\prime} 42^{\prime \prime}$ & $70^{\circ} 27^{\prime} 37^{\prime \prime}$ & & & 1 & & & 2005 \\
\hline Tacna/Churuyo & $17^{\circ} 01^{\prime} 48^{\prime \prime}$ & $69^{\circ} 57^{\prime} 43^{\prime \prime}$ & 4563 & 2 & & & & 2002 \\
\hline Puno/Laraqueri & $16^{\circ} 08^{\prime} 59^{\prime \prime}$ & $70^{\circ} 03^{\prime} 47^{\prime \prime}$ & 3973 & 1 & & & & 2002 \\
\hline Puno/Tiquillaca & $15^{\circ} 47^{\prime} 58^{\prime \prime}$ & $70^{\circ} 10^{\prime} 46^{\prime \prime}$ & 3887 & 1 & & & & 2002 \\
\hline Puno/near Jijuaña & $17^{\circ} 13^{\prime} 50^{\prime \prime}$ & $69^{\circ} 53^{\prime} 40^{\prime \prime}$ & 4400 & 13 & & & & 2005 \\
\hline Puno/Hacienda Ucumani & $15^{\circ} 52^{\prime} 14^{\prime \prime}$ & $70^{\circ} 11^{\prime} 50^{\prime \prime}$ & 3992 & 1 & & & & 2002 \\
\hline Puno/El Collao & $16^{\circ} 42^{\prime} 55^{\prime \prime}$ & $69^{\circ} 43^{\prime} 38^{\prime \prime}$ & & & & 5 & & 2004 \\
\hline Puno/El Collao & $17^{\circ} 08^{\prime} 09^{\prime \prime}$ & $69^{\circ} 41^{\prime} 54^{\prime \prime}$ & & & & 1 & & 2004 \\
\hline Puno/El Collao & $17^{\circ} 08^{\prime} 05^{\prime \prime}$ & $69^{\circ} 45^{\prime} 49^{\prime \prime}$ & & & & 1 & & 2004 \\
\hline Puno/El Collao & $17^{\circ} 08^{\prime} 06^{\prime \prime}$ & $69^{\circ} 46^{\prime} 19^{\prime \prime}$ & & & & 1 & & 2004 \\
\hline Puno/Tiracollo & $17^{\circ} 02^{\prime} 12^{\prime \prime}$ & $69^{\circ} 41^{\prime} 44^{\prime \prime}$ & 4199 & 1 & & & & 2002 \\
\hline Puno/Pisacoma & $16^{\circ} 54^{\prime} 30^{\prime \prime}$ & $69^{\circ} 22^{\prime} 15^{\prime \prime}$ & 3934 & 1 & & & & 2002 \\
\hline
\end{tabular}


Appendix 1 (continued)

\begin{tabular}{|c|c|c|c|c|c|c|c|c|}
\hline Department/locality & South & West & Altitude (m) & Skins & Dead cats & Scats & Sights & Year \\
\hline Puno/Arakachi & $16^{\circ} 41^{\prime} 39^{\prime \prime}$ & $69^{\circ} 14^{\prime} 24^{\prime \prime}$ & 3856 & 1 & & & & 2002 \\
\hline Puno/Tanca & $16^{\circ} 35^{\prime} 10^{\prime \prime}$ & $69^{\circ} 15^{\prime} 36^{\prime \prime}$ & 3868 & 2 & & & & 2002 \\
\hline Puno/Huaychacarani & $14^{\circ} 52^{\prime} 41^{\prime \prime}$ & $69^{\circ} 56^{\prime} 09^{\prime \prime}$ & 4202 & 1 & & & & 2002 \\
\hline Puno/Paccha & $11^{\circ} 27^{\prime} 58^{\prime \prime}$ & $75^{\circ} 57^{\prime} 49^{\prime \prime}$ & 3725 & 1 & & & & 2002 \\
\hline Puno/Calera & $15^{\circ} 21^{\prime} 16^{\prime \prime}$ & $70^{\circ} 22^{\prime} 29^{\prime \prime}$ & & 1 & & & & 2004 \\
\hline Puno/Lampa & $15^{\circ} 21^{\prime} 52^{\prime \prime}$ & $70^{\circ} 21^{\prime} 58^{\prime \prime}$ & & & & 4 & & 2004 \\
\hline Puno/Lampa & $15^{\circ} 15^{\prime} 41^{\prime \prime}$ & $70^{\circ} 28^{\prime} 45^{\prime \prime}$ & & 1 & & & & 2004 \\
\hline Puno/Lampa & $15^{\circ} 21^{\prime} 54^{\prime \prime}$ & $70^{\circ} 21^{\prime} 58^{\prime \prime}$ & & 1 & & & & 2004 \\
\hline Moquegua/Titire & $16^{\circ} 40^{\prime} 53^{\prime \prime}$ & $70^{\circ} 22^{\prime} 47^{\prime \prime}$ & & 1 & & & & 2005 \\
\hline Apurímac/Cerro Quilchiua & $13^{\circ} 48^{\prime} 05^{\prime \prime}$ & $72^{\circ} 29^{\prime} 31^{\prime \prime}$ & & & & 1 & & 2004 \\
\hline Apurimac/Pachacpata & $14^{\circ} 02^{\prime} 57^{\prime \prime}$ & $72^{\circ} 57^{\prime} 51^{\prime \prime}$ & & & & 1 & & 2004 \\
\hline Apurimac/Apurímac & $13^{\circ} 36^{\prime} 25^{\prime \prime}$ & $73^{\circ} 15^{\prime} 59^{\prime \prime}$ & & & & 1 & & 2004 \\
\hline Apurimac/Pachachaca & $13^{\circ} 39^{\prime} 33^{\prime \prime}$ & $72^{\circ} 56^{\prime} 40^{\prime \prime}$ & & & & 1 & & 2004 \\
\hline Apurimac/Pairaca & $14^{\circ} 17^{\prime} 28^{\prime \prime}$ & $73^{\circ} 15^{\prime} 14^{\prime \prime}$ & & & & 1 & & 2004 \\
\hline Apurimac/Haquira & $14^{\circ} 12^{\prime} 45^{\prime \prime}$ & $72^{\circ} 11^{\prime} 22^{\prime \prime}$ & & 1 & & & & 2005 \\
\hline Apurimac/Cotabamba & $13^{\circ} 44^{\prime} 49^{\prime \prime}$ & $72^{\circ} 21^{\prime} 22^{\prime \prime}$ & & 1 & & & & 2005 \\
\hline Arequipa/Ararahui & $15^{\circ} 32^{\prime} 31^{\prime \prime}$ & $77^{\circ} 27^{\prime} 06^{\prime \prime}$ & 4274 & 1 & & & & 2002 \\
\hline Arequipa/near Yura & $16^{\circ} 14^{\prime} 03^{\prime \prime}$ & $71^{\circ} 39^{\prime} 41^{\prime \prime}$ & 2777 & & 1 & & & 2002 \\
\hline Arequipa/RNSAB & $15^{\circ} 41^{\prime} 15^{\prime \prime}$ & $71^{\circ} 01^{\prime} 09^{\prime \prime}$ & & & & 1 & & 2004 \\
\hline Arequipa/RNSAB & $15^{\circ} 46^{\prime} 11^{\prime \prime}$ & $71^{\circ} 27^{\prime} 49^{\prime \prime}$ & & & & 1 & & 2004 \\
\hline Arequipa/Condesuyos & $15^{\circ} 23^{\prime} 36^{\prime \prime}$ & $70^{\circ} 38^{\prime} 26^{\prime \prime}$ & & & & 2 & & 2004 \\
\hline Arequipa/Condesuyos & $15^{\circ} 19^{\prime} 11^{\prime \prime}$ & $72^{\circ} 40^{\prime} 41^{\prime \prime}$ & & & & 2 & & 2004 \\
\hline Arequipa/La Union & $15^{\circ} 06^{\prime} 49^{\prime \prime}$ & $72^{\circ} 40^{\prime} 46^{\prime \prime}$ & & & & 1 & & 2004 \\
\hline Arequipa/La Union & $15^{\circ} 07^{\prime} 22^{\prime \prime}$ & $72^{\circ} 39^{\prime} 58^{\prime \prime}$ & & & & 1 & & 2004 \\
\hline Ayacucho/near Coracora & $15^{\circ} 00^{\prime} 31^{\prime \prime}$ & $73^{\circ} 46^{\prime} 11^{\prime \prime}$ & 3175 & 5 & & & & 2002 \\
\hline Ayacucho/Upahuacho & $14^{\circ} 54^{\prime} 30^{\prime \prime}$ & $73^{\circ} 23^{\prime} 53^{\prime \prime}$ & 3405 & 1 & & & & 2002 \\
\hline Ayacucho/ Incuyo & $15^{\circ} 14^{\prime} 36^{\prime \prime}$ & $73^{\circ} 33^{\prime} 58^{\prime \prime}$ & 3350 & & & 1 & & 2002 \\
\hline Ayacucho/Pullo & $15^{\circ} 12^{\prime} 17^{\prime \prime}$ & $73^{\circ} 49^{\prime} 32^{\prime \prime}$ & 3200 & 1 & & & & 2002 \\
\hline Ayacucho/Huamanpampa & $15^{\circ} 02^{\prime} 53^{\prime \prime}$ & $73^{\circ} 46^{\prime} 27^{\prime \prime}$ & 3150 & 1 & & & & 2002 \\
\hline Ayacucho/Vilcas Huaman/Intihuatana & $15^{\circ} 10^{\prime} 41^{\prime \prime}$ & $73^{\circ} 44^{\prime} 11^{\prime \prime}$ & 3550 & 1 & & & & 2002 \\
\hline Ayacucho/Nacalla & $15^{\circ} 02^{\prime} 39^{\prime \prime}$ & $73^{\circ} 52^{\prime} 32^{\prime \prime}$ & 3520 & 1 & & & & 2002 \\
\hline Ayacucho/Pampa Galeras & $14^{\circ} 39^{\prime} 44^{\prime \prime}$ & $74^{\circ} 22^{\prime} 13^{\prime \prime}$ & 4020 & 1 & & & & 2002 \\
\hline Ayacucho/Yaurihuiri lac & $14^{\circ} 35^{\prime} 30^{\prime \prime}$ & $73^{\circ} 57^{\prime} 03^{\prime \prime}$ & 4450 & & 2 & & & 2002 \\
\hline Ayacucho/Matará & $13^{\circ} 18^{\prime} 39^{\prime \prime}$ & $73^{\circ} 59^{\prime} 32^{\prime \prime}$ & 3500 & 1 & & & & 2002 \\
\hline Ayacucho/Yanahuanco bajo & $13^{\circ} 19^{\prime} 10^{\prime \prime}$ & $74^{\circ} 00^{\prime} 24^{\prime \prime}$ & 3680 & & 1 & & & 2002 \\
\hline Ayacucho/Cancha Cancha & $13^{\circ} 36^{\prime} 19^{\prime \prime}$ & $74^{\circ} 18^{\prime} 48^{\prime \prime}$ & 3350 & 1 & & & & 2002 \\
\hline Ayacucho/Huancapi & $13^{\circ} 45^{\prime} 09^{\prime \prime}$ & $74^{\circ} 03^{\prime} 57^{\prime \prime}$ & 3106 & & & 2 & & 2002 \\
\hline Ayacucho/Patacancha & $13^{\circ} 44^{\prime} 11^{\prime \prime}$ & $74^{\circ} 09^{\prime} 53^{\prime \prime}$ & 4040 & & & 1 & & 2002 \\
\hline Ayacucho/Canaria & $13^{\circ} 55^{\prime} 26^{\prime \prime}$ & $73^{\circ} 54^{\prime} 16^{\prime \prime}$ & 3100 & 2 & & & & 2002 \\
\hline Ayacucho/Querobamba & $14^{\circ} 00^{\prime} 54^{\prime \prime}$ & $73^{\circ} 50^{\prime} 28^{\prime \prime}$ & 3840 & 1 & & & & 2002 \\
\hline Ayacucho/Tintay & $14^{\circ} 04^{\prime} 43^{\prime \prime}$ & $73^{\circ} 51^{\prime} 54^{\prime \prime}$ & 4200 & 2 & & & & 2002 \\
\hline Cuzco/Auzangate & $13^{\circ} 44^{\prime} 37^{\prime \prime}$ & $71^{\circ} 12^{\prime} 14^{\prime \prime}$ & & 1 & & 4 & & 2004 \\
\hline Lima/Huancanayoc & $10^{\circ} 30^{\prime} 38^{\prime \prime}$ & $76^{\circ} 58^{\prime} 07^{\prime \prime}$ & & 1 & & & & 2005 \\
\hline Lima/Matucana & $11^{\circ} 53^{\prime} 04^{\prime \prime}$ & $76^{\circ} 26^{\prime} 23^{\prime \prime}$ & & & 1 & & & 2001 \\
\hline Lima/La Oroya & $11^{\circ} 37^{\prime} 37^{\prime \prime}$ & $76^{\circ} 01^{\prime} 00^{\prime \prime}$ & 4057 & & & 1 & & 2006 \\
\hline Lima/Tanta & $12^{\circ} 07^{\prime} 17^{\prime \prime}$ & $76^{\circ} 01^{\prime} 27^{\prime \prime}$ & 3876 & & & 2 & & 2006 \\
\hline Lima/Tanta & $12^{\circ} 02^{\prime} 42^{\prime \prime}$ & $75^{\circ} 58^{\prime} 18^{\prime \prime}$ & 4433 & & & 1 & & 2006 \\
\hline Lima/Tanta & $12^{\circ} 01^{\prime} 49^{\prime \prime}$ & $75^{\circ} 58^{\prime} 15^{\prime \prime}$ & 4476 & & & 5 & & 2006 \\
\hline Lima/Tanta & $12^{\circ} 04^{\prime} 00^{\prime \prime}$ & $75^{\circ} 56^{\prime} 53^{\prime \prime}$ & 4142 & & & 6 & & 2006 \\
\hline Lima/Tanta & $12^{\circ} 03^{\prime} 54^{\prime \prime}$ & $75^{\circ} 56^{\prime} 33^{\prime \prime}$ & 4126 & & & 1 & & 2006 \\
\hline Lima/Tanta & $12^{\circ} 05^{\prime} 04^{\prime \prime}$ & $75^{\circ} 57^{\prime} 14^{\prime \prime}$ & 4217 & & & 1 & & 2006 \\
\hline Lima/Tanta & $12^{\circ} 14^{\prime} 12^{\prime \prime}$ & $76^{\circ} 00^{\prime} 29^{\prime \prime}$ & 4481 & & & 2 & & 2006 \\
\hline Lima/Tanta & $12^{\circ} 13^{\prime} 58^{\prime \prime}$ & $76^{\circ} 00^{\prime} 34^{\prime \prime}$ & 4540 & & & 2 & & 2006 \\
\hline Lima/Tanta & $12^{\circ} 09^{\prime} 38^{\prime \prime}$ & $75^{\circ} 59^{\prime} 27^{\prime \prime}$ & 4578 & & & 1 & & 2006 \\
\hline Lima/Huaros & $11^{\circ} 24^{\prime} 19^{\prime \prime}$ & $76^{\circ} 34^{\prime} 26^{\prime \prime}$ & & 2 & & & & 2006 \\
\hline Junin/Canchayllo & $11^{\circ} 50^{\prime} 24^{\prime \prime}$ & $75^{\circ} 41^{\prime} 41^{\prime \prime}$ & 3959 & & & 1 & & 2006 \\
\hline Junin/Canchayllo & $11^{\circ} 49^{\prime} 49^{\prime \prime}$ & $75^{\circ} 41^{\prime} 59^{\prime \prime}$ & 3890 & & & 3 & & 2006 \\
\hline Junin/Canchayllo & $11^{\circ} 51^{\prime} 36^{\prime \prime}$ & $75^{\circ} 45^{\prime} 35^{\prime \prime}$ & 3847 & & & 7 & & 2006 \\
\hline Ancash/Huayhuash & $10^{\circ} 12^{\prime} 51^{\prime \prime}$ & $76^{\circ} 56^{\prime} 11^{\prime \prime}$ & & & & 12 & & 2006 \\
\hline Junin/Junin National Reserve & $11^{\circ} 00^{\prime} 45^{\prime \prime}$ & $76^{\circ} 01^{\prime} 43^{\prime \prime}$ & & 4 & 1 & 22 & 2 & $2005 / 2006$ \\
\hline Pasco/Huayllay & $10^{\circ} 56^{\prime} 07^{\prime \prime}$ & $76^{\circ} 20^{\prime} 15^{\prime \prime}$ & & & 1 & 15 & & $2005 / 2006$ \\
\hline Ancash/Recuay & $10^{\circ} 08^{\prime} 17^{\prime \prime}$ & $77^{\circ} 20^{\prime} 54^{\prime \prime}$ & 4230 & & & 1 & & 2006 \\
\hline Ancash/Recuay & $10^{\circ} 05^{\prime} 26^{\prime \prime}$ & $77^{\circ} 21^{\prime} 43^{\prime \prime}$ & 4256 & & & 1 & & 2006 \\
\hline Ancash/Recuay & $10^{\circ} 06^{\prime} 40^{\prime \prime}$ & $77^{\circ} 23^{\prime} 20^{\prime \prime}$ & 4025 & & & 1 & & 2006 \\
\hline Ancash/Recuay & $10^{\circ} 07^{\prime} 01^{\prime \prime}$ & $77^{\circ} 23^{\prime} 49^{\prime \prime}$ & 4129 & & & 2 & & 2006 \\
\hline Ancash/Recuay & $10^{\circ} 06^{\prime} 02^{\prime \prime}$ & $77^{\circ} 24^{\prime} 52^{\prime \prime}$ & 4356 & & & 1 & & 2006 \\
\hline Ancash/Recuay & $10^{\circ} 05^{\prime} 51^{\prime \prime}$ & $77^{\circ} 18^{\prime} 50^{\prime \prime}$ & 4235 & & & 1 & & 2006 \\
\hline Ancash/Recuay & $10^{\circ} 06^{\prime} 10^{\prime \prime}$ & $77^{\circ} 19^{\prime} 07^{\prime \prime}$ & 4423 & & & 1 & & 2006 \\
\hline Ancash/Recuay & $10^{\circ} 05^{\prime} 52^{\prime \prime}$ & $77^{\circ} 18^{\prime} 53^{\prime \prime}$ & 4486 & & & 2 & & 2006 \\
\hline Ancash/Recuay & $10^{\circ} 06^{\prime} 32^{\prime \prime}$ & $77^{\circ} 19^{\prime} 25^{\prime \prime}$ & 4329 & & & 1 & & 2006 \\
\hline Ancash/Recuay & $10^{\circ} 06^{\prime} 31^{\prime \prime}$ & $77^{\circ} 27^{\prime} 20^{\prime \prime}$ & 4156 & & & 1 & & 2006 \\
\hline Ancash/Recuay & $10^{\circ} 06^{\prime} 39^{\prime \prime}$ & $77^{\circ} 27^{\prime} 24^{\prime \prime}$ & 4523 & & & 1 & & 2006 \\
\hline Ancash/Recuay & $10^{\circ} 06^{\prime} 48^{\prime \prime}$ & $77^{\circ} 27^{\prime} 18^{\prime \prime}$ & 4462 & & & 1 & & 2006 \\
\hline Ancash/Recuay & $10^{\circ} 07^{\prime} 00^{\prime \prime}$ & $77^{\circ} 27^{\prime} 35^{\prime \prime}$ & 4451 & & & 1 & & 2006 \\
\hline Ancash/Recuay & $10^{\circ} 07^{\prime} 12^{\prime \prime}$ & $77^{\circ} 27^{\prime} 51^{\prime \prime}$ & 4435 & & & 1 & & 2006 \\
\hline Ancash/Recuay & $10^{\circ} 07^{\prime} 21^{\prime \prime}$ & $77^{\circ} 28^{\prime} 23^{\prime \prime}$ & 4445 & & & 2 & & 2006 \\
\hline Ancash/Recuay & $10^{\circ} 06^{\prime} 34^{\prime \prime}$ & $77^{\circ} 27^{\prime} 37^{\prime \prime}$ & 4458 & & & 1 & & 2006 \\
\hline Ancash/Recuay & $10^{\circ} 06^{\prime} 21^{\prime \prime}$ & $77^{\circ} 27^{\prime} 32^{\prime \prime}$ & 4399 & & & 1 & & 2006 \\
\hline Ancash/Huaraz & $09^{\circ} 32^{\prime} 33^{\prime \prime}$ & $77^{\circ} 25^{\prime} 12^{\prime \prime}$ & 4582 & & & 2 & & 2006 \\
\hline
\end{tabular}


Appendix 1 (continued)

\begin{tabular}{|c|c|c|c|c|c|c|c|c|}
\hline Department/locality & South & West & Altitude $(\mathrm{m})$ & Skins & Dead cats & Scats & Sights & Year \\
\hline Ancash/Huaraz & $09^{\circ} 32^{\prime} 33^{\prime \prime}$ & $77^{\circ} 24^{\prime} 52^{\prime \prime}$ & 4877 & & & 1 & & 2006 \\
\hline Ancash/Huaraz & $09^{\circ} 32^{\prime} 29^{\prime \prime}$ & $77^{\circ} 24^{\prime} 44^{\prime \prime}$ & 4577 & & & 2 & & 2006 \\
\hline Ancash/Huaraz & $09^{\circ} 32^{\prime} 18^{\prime \prime}$ & $77^{\circ} 24^{\prime} 43^{\prime \prime}$ & 4589 & & & 1 & & 2006 \\
\hline Ancash/Huaraz & $09^{\circ} 32^{\prime} 11^{\prime \prime}$ & $77^{\circ} 24^{\prime} 40^{\prime \prime}$ & 4558 & & & 1 & & 2006 \\
\hline Ancash/Huaraz & $09^{\circ} 32^{\prime} 12^{\prime \prime}$ & $77^{\circ} 24^{\prime} 26^{\prime \prime}$ & 4560 & & & 3 & & 2006 \\
\hline Ancash/Huaraz & $09^{\circ} 32^{\prime} 23^{\prime \prime}$ & $77^{\circ} 24^{\prime} 15^{\prime \prime}$ & 4532 & & & 1 & & 2006 \\
\hline Ancash/Huaraz & $09^{\circ} 32^{\prime} 27^{\prime \prime}$ & $77^{\circ} 24^{\prime} 14^{\prime \prime}$ & 4235 & & & 1 & & 2006 \\
\hline Ancash/Huaraz & $09^{\circ} 32^{\prime} 30^{\prime \prime}$ & $77^{\circ} 24^{\prime} 11^{\prime \prime}$ & 4243 & & & 1 & & 2006 \\
\hline Ancash/Huaraz & $09^{\circ} 32^{\prime} 32^{\prime \prime}$ & $77^{\circ} 24^{\prime} 18^{\prime \prime}$ & 4532 & & & 1 & & 2006 \\
\hline Ancash/Huaraz & $09^{\circ} 32^{\prime} 35^{\prime \prime}$ & $77^{\circ} 24^{\prime} 24^{\prime \prime}$ & 4102 & & & 1 & & 2006 \\
\hline Ancash/Huaraz & $09^{\circ} 32^{\prime} 56^{\prime \prime}$ & $77^{\circ} 23^{\prime} 46^{\prime \prime}$ & 4487 & & & 2 & & 2006 \\
\hline Ancash/Huaraz & $09^{\circ} 33^{\prime} 04^{\prime \prime}$ & $77^{\circ} 23^{\prime} 56^{\prime \prime}$ & 4857 & & & 1 & & 2006 \\
\hline Ancash/Huaraz & $09^{\circ} 33^{\prime} 09^{\prime \prime}$ & $77^{\circ} 23^{\prime} 55^{\prime \prime}$ & 4902 & & & 2 & & 2006 \\
\hline Ancash/Huaraz & $09^{\circ} 33^{\prime} 10^{\prime \prime}$ & $77^{\circ} 23^{\prime} 55^{\prime \prime}$ & 4920 & & & 1 & & 2006 \\
\hline Ancash/Huaraz & $09^{\circ} 43^{\prime} 28^{\prime \prime}$ & $77^{\circ} 17^{\prime} 31^{\prime \prime}$ & 4565 & & & 2 & & 2006 \\
\hline Ancash/Huaraz & $09^{\circ} 43^{\prime} 34^{\prime \prime}$ & $77^{\circ} 17^{\prime} 04^{\prime \prime}$ & 4423 & & & 2 & & 2006 \\
\hline Ancash/Huaraz & $09^{\circ} 30^{\prime} 23^{\prime \prime}$ & $77^{\circ} 25^{\prime} 17^{\prime \prime}$ & 4687 & & & 2 & & 2006 \\
\hline Ancash/Huaraz & $09^{\circ} 30^{\prime} 28^{\prime \prime}$ & $77^{\circ} 25^{\prime} 08^{\prime \prime}$ & 4586 & & & 1 & & 2006 \\
\hline Ancash/Huaraz & $09^{\circ} 30^{\prime} 38^{\prime \prime}$ & $77^{\circ} 24^{\prime} 51^{\prime \prime}$ & 4721 & & & 2 & & 2006 \\
\hline Ancash/Huaraz & $09^{\circ} 30^{\prime} 36^{\prime \prime}$ & $77^{\circ} 24^{\prime} 26^{\prime \prime}$ & 4690 & & & 1 & & 2006 \\
\hline Ancash/Huaraz & $09^{\circ} 30^{\prime} 20^{\prime \prime}$ & $77^{\circ} 24^{\prime} 23^{\prime \prime}$ & 4982 & & & 2 & & 2006 \\
\hline Ancash/Chacas & $09^{\circ} 13^{\prime} 49^{\prime \prime}$ & $77^{\circ} 27^{\prime} 10^{\prime \prime}$ & & & & 3 & & 2004 \\
\hline Ancash/Vicos & $09^{\circ} 20^{\prime} 01^{\prime \prime}$ & $77^{\circ} 30^{\prime} 51^{\prime \prime}$ & & & & 3 & & 2004 \\
\hline Batán Grande & $06^{\circ} 28^{\prime} 59^{\prime \prime}$ & $79^{\circ} 39^{\prime} 57^{\prime \prime}$ & & 1 & & & 1 & 2003 \\
\hline Lambayeque/Incawasi & $06^{\circ} 14^{\prime} 28^{\prime \prime}$ & $79^{\circ} 16^{\prime} 43^{\prime \prime}$ & & & & 1 & & 2005 \\
\hline Lambayeque/Shupicaga & $06^{\circ} 13^{\prime} 31^{\prime \prime}$ & $79^{\circ} 20^{\prime} 17^{\prime \prime}$ & & & & 1 & & 2005 \\
\hline Lambayeque/Kampanayqu & $06^{\circ} 14^{\prime} 06^{\prime \prime}$ & $79^{\circ} 20^{\prime} 45^{\prime \prime}$ & & & & 2 & & 2005 \\
\hline Lambayeque/Incawasi & $06^{\circ} 13^{\prime} 13^{\prime \prime}$ & $79^{\circ} 17^{\prime} 58^{\prime \prime}$ & & & & 1 & & 2005 \\
\hline Total & & & & 67 & 5 & 183 & 5 & \\
\hline
\end{tabular}

Appendix 2. Lynchailurus colocolo. Pampas cat records in Peru from other sources. MUSM: Museo de Historia Natural de la Universidad Nacional de San Marcos, Lima

\begin{tabular}{|lllr|}
\hline Department/locality & South & West & Altitude (m) \\
\hline Amazonas/Condechaca & $05^{\circ} 30^{\prime}$ & $78^{\circ} 32^{\prime}$ & Source \\
San Martín/Río Abiseo & $07^{\circ} 39^{\prime}$ & $77^{\circ} 30^{\prime}$ & García-Perea (1994) \\
Arequipa/Atiquipa & $15^{\circ} 47^{\prime} 46^{\prime \prime}$ & $74^{\circ} 21^{\prime} 49^{\prime \prime}$ & Romo (1995) \\
Huanuco/Ambo & $10^{\circ} 05^{\prime}$ & $76^{\circ} 07^{\prime}$ & Zeballos et al. (2000) \\
Pasco/Huariaca & $10^{\circ} 27^{\prime}$ & $76^{\circ} 07^{\prime}$ & García-Perea (1994) \\
Lima/Lima/Lurin & $12^{\circ} 13^{\prime} 04.80^{\prime \prime}$ & $76^{\circ} 48^{\prime} 03.24^{\prime \prime}$ & García-Perea (1994) \\
Lima/Huaura/Huacho & $11^{\circ} 21^{\prime}$ & $77^{\circ} 22^{\prime} 59.88^{\prime \prime}$ & MUS unpubl. \\
Cuzco/Hacienda & $13^{\circ} 28^{\prime}$ & $71^{\circ} 25^{\prime}$ & 3500-4000 unpubl. \\
Campana & $14^{\circ} 21^{\prime} 56.52^{\prime \prime}$ & $75^{\circ} 40^{\prime} 57.72^{\prime \prime}$ & 2500 \\
Ica/Ica/Ocucaje & & & García-Perea (1994) \\
\hline
\end{tabular}

Editorial responsibility: Dave Hodgson,

University of Exeter, Cornwall Campus, UK
Submitted: June 5, 2007; Accepted: October 5, 2007

Proofs received from author(s): November 12, 2007 